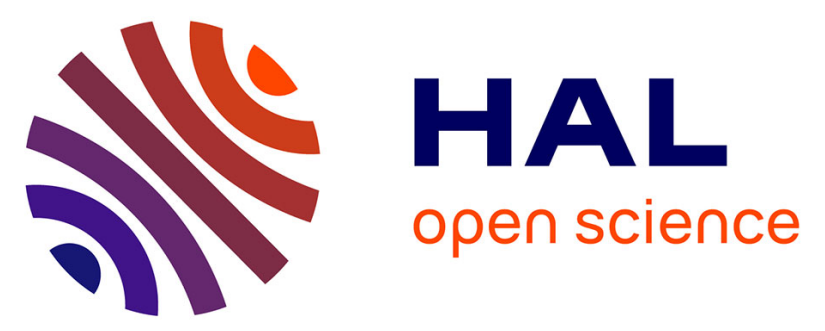

\title{
Fine genetic mapping of a gene required for Rice yellow mottle virus cell-to-cell movement
}

\author{
Laurence Albar, M.N. Ndjiondjop, Z. Esshak, A. Berger, Agnès Pinel, M.
}

Jones, Denis Fargette, Alain Ghesquière

\section{To cite this version:}

Laurence Albar, M.N. Ndjiondjop, Z. Esshak, A. Berger, Agnès Pinel, et al.. Fine genetic mapping of a gene required for Rice yellow mottle virus cell-to-cell movement. TAG Theoretical and Applied Genetics, 2003, 107 (2), pp.371-378. 10.1007/s00122-003-1258-4 . ird-01223710

\author{
HAL Id: ird-01223710 \\ https://hal.ird.fr/ird-01223710
}

Submitted on 3 Nov 2015

HAL is a multi-disciplinary open access archive for the deposit and dissemination of scientific research documents, whether they are published or not. The documents may come from teaching and research institutions in France or abroad, or from public or private research centers.
L'archive ouverte pluridisciplinaire HAL, est destinée au dépôt et à la diffusion de documents scientifiques de niveau recherche, publiés ou non, émanant des établissements d'enseignement et de recherche français ou étrangers, des laboratoires publics ou privés. 


\title{
Fine genetic mapping of a gene required for Rice yellow mottle virus cell-to-cell movement
}

\author{
L. Albar ( $₫) \cdot$ M.-N. Ndjiondjop · Z. Esshak $\cdot$ A. Berger $\cdot$ A. Pinel $\cdot$ M. Jones $\cdot$ D. Fargette \\ - A. Ghesquière
}

L. Albar $\cdot$ Z. Esshak $\cdot$ A. Berger $\cdot$ A. Pinel $\cdot$ D. Fargette $\cdot$ A. Ghesquière IRD, BP5045, 34032 Montpellier cedex 1, France

M.-N. Ndjiondjop · M. Jones

WARDA/ADRAO, 01 BP 2551, Bouaké, Republic of Ivory Coast

L. Albar

Fax: +33-467-416181

E-mail: laurence.albar@mpl.ird.fr

Received: 29 July 2002 / Accepted: 25 November 2002

\begin{abstract}
The very high resistance to rice yellow mottle virus observed in the two rice varieties Gigante (Oryza sativa) and Tog 5681 (O. glaberrima) is monogenic and recessive. Bulked segregant analysis was carried out to identify AFLP markers linked to the resistance gene. Mapping of PCR-specific markers, CAPS and microsatellite markers on 429 individuals of an IR64 $\times$ Gigante $F_{2}$ population pinpointed this resistance gene on the long arm of chromosome 4 in a 3.7-cM interval spanned by PCR markers. These markers also flanked the resistance gene of the O.glaberrima accession Tog 5681 and confirmed previous allelism tests. The rarity of this recessive natural resistance was in line with a resistance mechanism model based on point mutations of a host component required for cell-to-cell movement of the virus. Preliminary data on the genetic divergence between the two cultivated rice species in the vicinity of the resistance locus suggested that two different resistance alleles are present in Gigante and Tog 5681. A large set of recombinants is now available to envisage physical mapping and cloning of the gene.
\end{abstract}

Keywords. Amplified fragment length polymorphism $\cdot$ Microsatellite markers $\cdot$ Resistance gene $\cdot$ Rice $\cdot$ Rice yellow mottle virus 


\section{Introduction}

The isolation of more plant resistance genes substantially increases our knowledge of the mechanisms developed by plants to resist virus infection. Some virus resistance genes belong to the large class of NBS-LRR (leucino-rich repeat) genes usually involved in a hypersensitive cell death (HR), which is one of the most documented resistance mechanisms. For instance, the $\mathrm{N}$ gene of tobacco, one of the first resistance genes isolated, induces an HR in response to tobacco mosaic virus inoculation (Whitham et al. 1994). The $R x$ gene of potato is another NBS-LRR gene that can induce HR but is also involved in extreme resistance, whereby potato virus X accumulation is rapidly stopped in infected cells (Bendahmane et al. 1999). Another kind of resistance results in the blockage of long-distance movement, described, for example in the interaction between Arabidopsis plants carrying RTM1 and RTM2 genes and tobacco etch potyvirus. RTM1 and RTM2 present no sequence similarity with most of the resistance genes described to date and code for lectin-like and HSP-like proteins, respectively (Chisholm et al. 2000; Whitham et al. 2000). Studies on their expression profiles and interactions with plant or virus proteins will help in understanding their role in the restriction of long-distance movement. Plants can also limit virus infection by developing mechanisms to restrict cell-to-cell movement. Such a mechanism has been described in the resistance of tobacco plants with the va gene against tobacco vein mottling virus (Gibb et al. 1989).

Hypotheses concerning the putative function of resistance genes involved in this mechanism have been proposed (Gibb et al. 1989), but no genes involved in cell-to-cell movement have yet been cloned.

Extensive studies are under way in our laboratory on the interaction between rice and Rice yellow mottle virus (RYMV). This work is motivated both by the economic importance of the disease and by the characteristics of this interaction, which could serve as a model for studying various aspects of resistance mechanisms, such as partial resistance, tolerance or high resistance. In particular, our purpose is the isolation of a major resistance gene involved in the restriction of cell-to-cell movement in order to understand molecular interactions 
associated with this mechanism and to optimise the agronomic use of this resistance. In this article, we report the first step of this approach, which involves fine mapping of the gene.

RYMV is one of the main viruses affecting rice crops. This virus is restricted to the African continent and is responsible for major crop losses in irrigated conditions (Abo et al. 1998). Early infection leads to plant death in highly susceptible varieties, such as the high-yielding and widely grown variety, IR64. Different levels of resistance have been described in the two cultivated rice species, Oryza sativa and $O$. glaberrima. Some upland O. sativa cultivars showed partial resistance associated with tolerance under polygenic control (Albar et al. 1998), and high resistance was observed in five O. glaberrima accessions, including Tog 5672 and Tog 5681 (Thottappilly and Rossel 1993), and the O. sativa cultivar Gigante (Ndjiondjop et al. 1999). These varieties expressed no symptoms after mechanical inoculation with RYMV, and virus content estimated 2 weeks after infection using an ELISA test was not significant. This promising resistance has been characterised genetically and phenotypically and is currently introgressed by a classical backcross selection scheme into high-yielding varieties. A high virus content in Gigante and Tog 5681 protoplasts and cytological studies suggest that this resistance results from impaired cell-to-cell movement of the virus (Ndjiondjop et al. 2001). The genetic basis of this resistance has been studied in IR64 $\times$ Gigante and IR64 $\times$ Tog 5681 crosses. The resistance is under the control of one recessive gene and the same locus is involved in the two varieties (Ndjiondjop et al. 1999).

In the investigation reported here, we have used a population derived from the IR64 $\times$ Gigante cross to initiate positional cloning of the Gigante resistance gene. Amplified fragment length polymorphism (AFLP) and microsatellite markers closely linked to the gene have been identified and mapped. The best marker identified is now close enough to the gene to start physical mapping.

\section{Materials and methods}

\section{Plant material}

The plant populations derived from var. IR64, which is susceptible to RYMV, and the two highly resistant varieties Gigante and Tog 5681. IR64 (O. sativa) is a high-yielding cultivar developed at IRRI. Tog 5681 (Oryza glaberrima) and Gigante (O. sativa) were kindly provided by WARDA (West African Rice Development Association). A IR64 $\times$ Gigante $F_{2}$ population 
was developed in several steps to finally reach over 1,100 individuals screened for RYMV resistance and/or markers spanning the RYMV resistance locus: (1) 55 individuals developed to assess the genetic basis of the high resistance to RYMV (Ndjiondjop et al. 1999) were used for the selection of resistant and susceptible pools for bulked segregant analysis (BSA) (Michelmore et al. 1991) of AFLP markers; this population was extended to 291 individuals for fine mapping by microsatellite markers; 138 additional resistant individuals derived from direct inoculation of $768 \mathrm{~F}_{2}$ plants were scored for markers to increase the recombinant population size and determine the position of AFLP candidate markers in the target region. A backcross population of 47 individuals was also developed from the IR64 $\times$ Tog 5681 cross using Tog 5681 as recurrent parent. The IR64 $\times$ Azucena population, made of doubled-haploid (DH) lines, was used to anchor the gene on a reference map. This population was developed by Guiderdoni et al. (1992) and has been used in several studies (Ghesquière et al. 1996; Huang et al. 1997; Lorieux et al. 1996; Yadav et al. 1997).

Different varieties of the two cultivated rice species were analysed to gain some insight into the diversity of the chromosome portion bearing the resistant locus. Highly resistant varieties (Tog 5681, Tog 5672) and susceptible varieties (CG14, CG17, CG20, IG10, SG329, Tog 5673) of $O$. glaberrima were selected as well as a representative set of $O$. sativa lines, including indica and japonica lines with various degrees of susceptibility to RYMV.

\section{Evaluation of RYMV resistance}

RYMV resistance was assessed on the basis of symptom intensity. Plants were grown in a growth chamber under $12 \mathrm{~h}$ of light, at $28 \pm 1{ }^{\circ} \mathrm{C}$ (day) and $26 \pm 1{ }^{\circ} \mathrm{C}$ (night). Two weeks after sowing, plants were inoculated with an RYMV isolate from Burkina Faso, as described in Ndjiondjop et al. (1999). Between 2 weeks and 4 weeks post-inoculation, symptoms were observed at different dates. Susceptible plants usually showed clear yellow mottles on leaves, and resistant plants had no symptoms at all. When the symptoms were not distinct enough, ELISA tests were performed as described in Ndjiondjop et al. (1999).

Different strategies were used to assess the resistance of $F_{2}$ individuals. Selection of $F_{2}$ resistant plants was based on inoculation of the $F_{2}$ generation: susceptible plants died a few weeks after inoculation and only resistant ones were analysed further. When susceptible plants had to be retained for further analysis, resistance tests were performed on the $\mathrm{F}_{3}$ generation. To set the bulks, resistance tests were performed on $20-30 \mathrm{~F}_{3}$ plants for each $\mathrm{F}_{2}$ plant. To screen a large $F_{2}$ population, tests were first performed on two $F_{3}$ plants, while $F_{2}$ 
plants were genotyped with microsatellite markers spanning the resistance locus. When both plants of a family were susceptible or when a recombination was detected, results were confirmed on ten additional $\mathrm{F}_{3}$ plants.

The resistance level of backcross plants was evaluated on cuttings in order to keep the plants healthy. Cuttings were inoculated when a new leaf had grown; symptoms were observed, and ELISA tests were performed as described previously.

\section{Molecular markers}

DNA was extracted from fresh or lyophilised leaves using the CTAB method (Murray and Thompson 1980).

The AFLP procedure was performed essentially as described by Vos et al. (1995) with minor modifications. A 250-ng sample of genomic DNA was digested using two restriction enzymes, EcoRI and MseI. Restriction fragments were ligated with double-strand adapters using T4 DNA ligase (Roche, Indianapolis, Ind.). Digested-ligated DNA fragments were used as templates for a first amplification using primers complementary to the adaptors but with one additional selective $3^{\prime}$ nucleotide. The reaction mix was diluted to $1 / 30$, and $10 \mu \mathrm{l}$ was used for the final amplification. The primers used for this amplification had a common sequence (5'-GACTGCGTACCAATTC-3', subsequently referred to as E-, on the EcoRI site, and 5'-GATGAGTCCTGAGTAA-3', referred as M-, on the MseI site) and three additional selective $3^{\prime}$ nucleotides. The primers used were: E-AAC, E-AAG, E-ACA, E-ACC, E-ACG, E-ACT, E-AGA, E-AGC, E-AGG, E-AGT, E-ATC, E-CAA, E-CAT, E-CTA and E-CTT on the EcoRI site, M-CAA, M-CAC, M-CAG, M-CAT, M-CCA, M-CCT, M-CGA, M-CGT, M-CTA, M-CTC, M-CTG, M-CTT, M-AAC, M-AAG, M-AAT, M-ACA, M-ACC, M-ACG, M-ACT, M-AGC, M-AGG and M-AGT on the MseI site. Polymerase chain reaction (PCR) amplifications were carried out in an MJ Research thermal controller (Watertown, Mass.). The amplification programme consisted of an initial cycle at $94{ }^{\circ} \mathrm{C}$ for $30 \mathrm{~s}, 65^{\circ} \mathrm{C}$ for $30 \mathrm{~s}, 72{ }^{\circ} \mathrm{C}$ for $60 \mathrm{~s}$, then 12 cycles of the same regime while lowering the annealing temperature by $0.7^{\circ} \mathrm{C}$ per cycle. This was followed by 32 cycles of $94{ }^{\circ} \mathrm{C}$ for $30 \mathrm{~s}, 56^{\circ} \mathrm{C}$ for $30 \mathrm{~s}, 72^{\circ} \mathrm{C}$ for $60 \mathrm{~s}$. For radioactive labelling, one of the primers (E) was end-labelled with $\gamma\left[{ }^{33} \mathrm{P}\right]$-ATP using T4 polynucleotide kinase. Amplification products were separated on a $6 \%$ denaturing polyacrylamide gel with $8 M$ urea and $1 \times$ TBE. The dried gels were exposed to Kodak Bio Max X-ray film. For silver staining, amplification with non-labelled primers and electrophoresis were performed as described previously. After migration, the gel was immersed 
in $10 \%$ acetic acid for $20 \mathrm{~min}$ and washed three times in distilled water. It was immersed for $1 \mathrm{~h}$ in $\mathrm{AgNO}_{3}(1 \%$ ), formaldehyde (0.55\%o) and, after washing, was revealed for a few minutes in $\mathrm{Na}_{2} \mathrm{CO}_{3}\left(30 \%\right.$ ), $\mathrm{Na}_{2} \mathrm{SO}_{3}(0.0045 \%$ ) , formaldehyde (1.1\%o). The staining was fixed in $10 \%$ acetic acid, and the gel was washed in water and dried.

Two AFLP fragments were cloned, sequenced and transformed into PCR-specific markers, named M1 and M3. After silver staining, selected bands were isolated and eluted in $50 \mu \mathrm{l}$ $\mathrm{H}_{2} \mathrm{O}$ overnight. An aliquot was re-amplified to check the size of the eluted fragment. Another aliquot was ligated in PGEM-T Easy plasmid using the protocol recommended by Promega (Madison, Wis.). Transformation was performed in the Escherichia coli JM109 strain. The plasmid was sent to Genome Express for sequencing. Different primers were deduced from the sequence obtained to specifically re-amplify the markers. Primers

5'-AGGAAGGGGAACACAACAGCC-3' and 5'-GCAGTTCCATGCTGAGCGCAT-3' were selected to specifically amplify M1 at an annealing temperature of $59{ }^{\circ} \mathrm{C}$. Primers 5'-ATTCACCCCATGCCCTAAG-3' and 5' -AACCTAAGGCCACCTCCAAT-3' were selected to specifically amplify M3 at an annealing temperature of $58^{\circ} \mathrm{C}$. Length polymorphism between IR64, Azucena and Gigante was analysed, as well as cleared amplified polymorphic sequence (CAPS) polymorphism for restriction enzymes cutting the sequence of the fragment in IR64.

The microsatellite markers RM241, RM273 and RM252 (Chen et al. 1997; Temnykh et al. 2000) were used. Amplification was performed as described in Chen et al. (1997) except that $0.4 \mu \mathrm{Ci}$ of $\alpha-\left[{ }^{33} \mathrm{P}\right]-\mathrm{dATP}$ was incorporated during the PCR. PCR products were run on $6 \%$ polyacrylamide gels, and the gels were exposed to X-ray film (Kodack Biomax) overnight.

\section{Mapping}

Mapping was carried out using MAPMAKER v3.0 (Lander et al. 1987). The recombination percentage between the RYMV resistance gene and several markers in the IR64 $\times$ Gigante $\mathrm{F}_{2}$ population and $(\mathrm{IR} 64 \times \operatorname{Tog} 5681) \times$ Tog 5681 were also estimated using the tables of Allard (1956). 


\section{Results}

\section{Identification of AFLP markers linked to the gene by bulked segregant analysis}

We used bulked segregant analysis (Michelmore et al. 1991) to identify AFLP markers linked to the resistance gene of Gigante. The susceptible (vs. resistant) bulks consisted of ten homozygous susceptible (vs. resistant) $F_{2}$ plants from the IR64 $\times$ Gigante cross. Three hundred and fifteen pairs of AFLP primers were tested on the bulks and vars IR64 and Gigante. The size of the fragments revealed after selective amplification ranged from $10 \mathrm{bp}$ to $500 \mathrm{bp}$. An average of 42 easily readable fragments were detected for each pair of primers, with $11 \%$ showing polymorphism between IR64 and Gigante; this amounts to about 13,000 fragments that were identified and about 1,400 that were polymorphic between parents.

Thirty-two pairs of primers revealed 42 bands showing polymorphism between resistant and susceptible bulks, which represents 3\% of the bands polymorphic between IR64 and Gigante. Twenty-one fragments were amplified from IR64 and the susceptible bulk and 21 from Gigante and the resistant bulk. Positive bands were confirmed by individually analysing the 20 plants constituting the bulks. Only those markers showing fewer than three visible recombinations with the gene - and apparently the most closely linked to it - were selected for further analysis. Fifteen bands from IR64 and ten from Gigante were retained.

\section{Development of STS and CAPS markers and anchoring on a reference genetic map}

To map easily the RYMV resistant locus on the IR64 $\times$ Azucena reference population as well as on the large IR64 $\times$ Gigante $F_{2}$ population, we attempted to derive STS (site-tagged-sequence) or CAPS markers from the two first AFLP markers identified as linked to the resistance gene.

M1, generated with the E-AAC/M-CAG primer combination, was a 510-bp fragment, with 486 bp specific to IR64 and 24 bp coming from the adaptators; it showed no homology with known sequences in databases. Primers were designed and used to amplify specific fragments in IR64, Azucena and Gigante. No length polymorphism was detected between amplified fragments, but a CAPS marker was generated using the MspI enzyme, as this enzyme cut 
the fragment amplified from IR64 but not the fragment amplified from Gigante and Azucena. Thus, a codominant CAPS marker was generated that could be used in the analysis of IR64 $\times$ Azucena and IR64 $\times$ Gigante populations.

M3, generated with the E-ACC/M-CAG combination, was 145 bp long, with 121 bp coming specifically from IR64, it showed 97\% homology with the OSJNBbo108011f sequence from the rice bacterial artificial chromosome (BAC) library from the Nipponbare variety (Chen et al. 2002). After testing different primers, specific PCR fragments were amplified from IR64 and Azucena but not from Gigante. M3 was consequently used as a STS dominant marker in the IR64 $\times$ Gigante population. However, no length polymorphism or CAPS marker useful for mapping M3 in the IR64 $\times$ Azucena population was identified, thus preventing M3 mapping in this population.

We mapped the CAPS marker M1 on $60 \mathrm{DH}$ lines of the reference population IR64 $\times$ Azucena. No segregation distortion was observed, and M1 was mapped on chromosome 4 between the R(restriction)FLP markers RG163 and RG214 in a 26-cM interval, without significant alteration of the genetic map.

\section{Fine mapping of the resistance locus by microsatellite markers}

Many microsatellite markers were available on chromosome 4. They are excellent tools for fine mapping of the resistance locus. A target zone (RM241-RM273) was determined by the microsatellite pattern in the $\mathrm{F}_{3}$ progeny of a double $\mathrm{M} 1-\mathrm{M} 3$ recombinant. Then we mapped markers RM241, RM252 and RM273 in an extended IR64 $\times$ Gigante $F_{2}$ population made of $291 \mathrm{~F}_{2}$ individuals characterised by a resistance test on $\mathrm{F}_{3}$ progeny as described in the Materials and methods. At the same time, we rapidly screened recombinants in the resistant fraction of another $F_{2}$ IR64 $\times$ Gigante sample: 768 IR64 $\times$ Gigante $F_{2}$ plants were inoculated with the virus and 138 resistant plants, homozygous for the Gigante allele, were selected. These resistant plants were analysed with M1 and M3, and recombinants were also analysed with microsatellite markers.

Among 291 plants from the first population and 768 from the second one selected for resistance, $21 \%$ (61) and $18 \%$ (138) were resistant, respectively, showing segregation distortion against resistant plants. As this distortion was found to be homogenous in the two $\mathrm{F}_{2}$ populations $\left(\chi^{2}=1.26 ; P>0.1\right)$, a bias against resistant plants due to very severe selection 
for the resistance phenotype in the second population was unlikely; it more likely reflected a segregation distortion phenomenon usually found in rice crosses (Xu et al. 1997). The data were then combined for mapping analysis using MAPMAKER V3.0, followed by two-point tests with the tables of Allard (1956). The results of mapping microsatellite, STS, CAPS and AFLP markers are presented in Fig. 1. The resistance gene is located between RM273 and RM252 and these markers were mapped $2.3 \mathrm{cM}$ and $1.8 \mathrm{cM}$ from the gene (or $2.3 \pm 0.5 \%$ and $1.8 \pm 0.5 \%$ recombination using two-point tests). An excess of double recombinants around the RYMV resistance locus was observed and slightly increased the interval between RM252 and RM273 compared to what was expected using a two-point test (3.5\% recombination). Finally, 28 plants that recombined once and three double-recombined plants between RM273 and RM252 were identified.

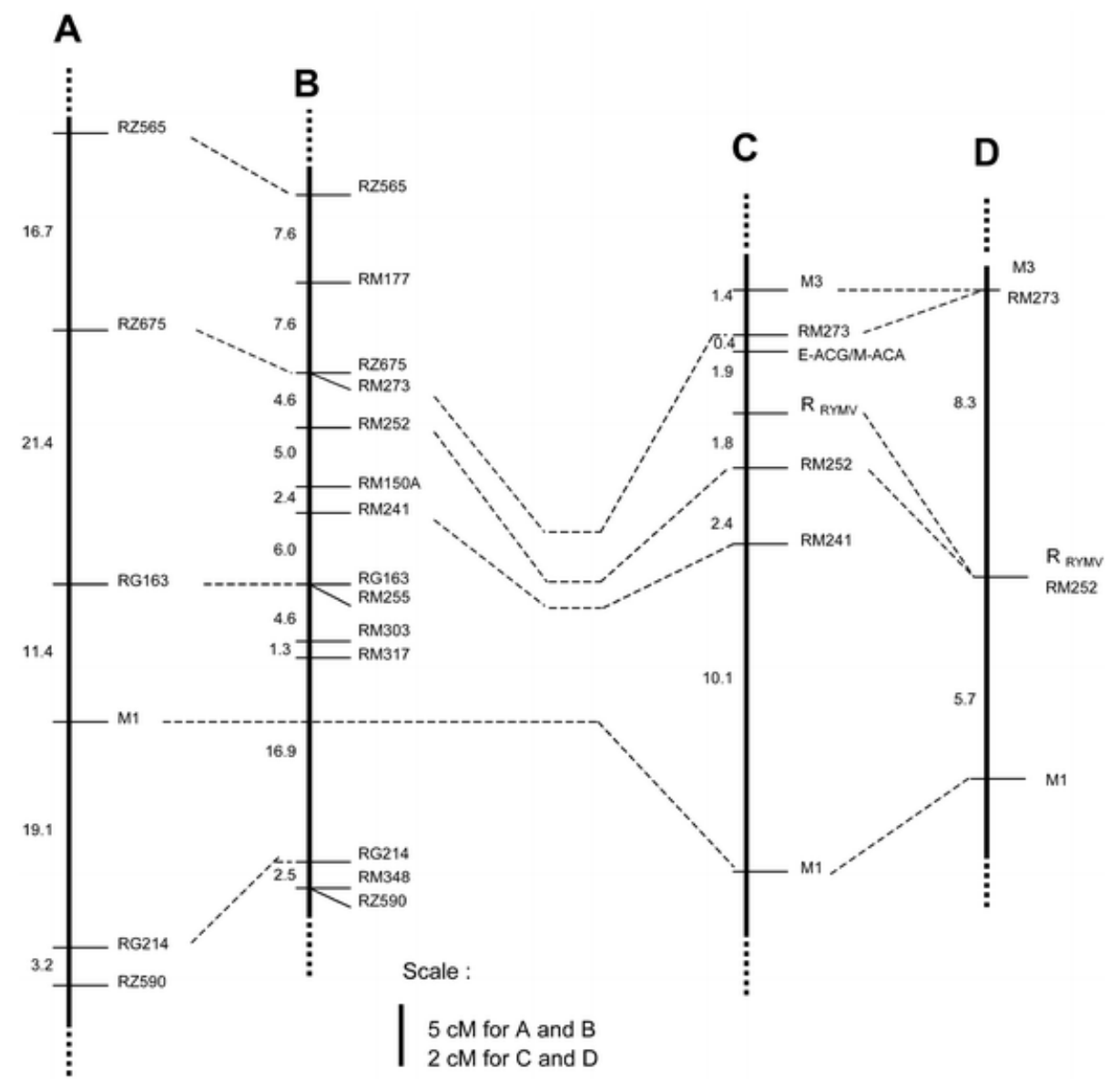

Fig. 1. Mapping of the RYMV resistance locus on the long arm of chromosome 4. Alignment of the maps obtained on the DH population IR64 $\times$ Azucena in our laboratory ( $A$; Albar et al. 1998) and in Cornell University [ $\left(B\right.$; Temnykh et al. 2000), on the $\mathrm{F}_{2}$ IR64 $\times$ Gigante population $(C)$ and the backcross $($ IR64 $\times$ Tog5681 $) \times$ Tog5681 population $(D)]$. Distances between markers are indicated in centiMorgans 


\section{Validation of candidate AFLP markers}

Based on the parental origin of the AFLP markers, recombinants were used to classify AFLP markers in the M1-M3 region. While both populations were fully informative when the AFLP bands came from IR64, only a complete $\mathrm{F}_{2}$ population could be used when an AFLP band originated from Gigante.

Finally, among the 25 AFLP candidate markers selected by BSA, 13 markers mapped outside the M1-M3 interval, six markers mapped in the interval M1-M241 and three markers mapped in the interval RM273-M3. Of the 25 markers, three pairs of markers behaved as three codominant markers. One marker, amplified from IR64 using E-ACG/M-ACA primers, mapped between the microsatellite markers RM273 and the resistance gene. On 12 informative events of recombination between the RYMV resistance locus and RM273, ten individuals gave a recombination pattern between the AFLP marker E-ACG/M-ACA and the RYMV resistance locus. The position of this marker was consequently estimated at $1.9 \mathrm{cM}$ of the RYMV resistance locus.

\section{Validation of the markers in the population (IR64 $\times$ Tog 5681) $\times$ Tog 5681}

Markers linked to the resistance gene in the IR64 $\times$ Gigante $F_{2}$ population were also analysed in the $($ IR64 $\times$ Tog 5681) $\times$ Tog 5681 backcross population. Microsatellite markers RM252 and RM273 were polymorphic between Tog5681 and IR64. As the AFLP markers M1 and M3 could be amplified in susceptible variety IR64 but not in Gigante and Tog 5681, they could also be used in the interspecific population.

The four markers were significantly linked to the resistance gene (LOD>3). No recombination was detected between M1 and RM273 on one hand and between RM252 and the resistance gene on the other hand. Despite the small number of available individuals, the order (M1/RM273) - (resistance gene/RM252) - M3 was far more probable than any other one (LOD difference $>1.7$ ) and gave the shorter map (Fig. 1). The marker order was in agreement with the map obtained on the IR64 $\times$ Gigante $F_{2}$ population. These data were supported by the interspecific map established by Lorieux et al. (2000), on which no inversion was detected in this region between the genome of $O$. glaberrima and $O$. sativa. The resistance gene of Tog5681 mapped in the RM273-M1 interval, close to RM252, confirming that the same locus is probably involved in the resistance of Gigante and Tog5681. 


\section{Diversity in rice varieties at the relevant locus}

Assuming that microsatellite markers RM273, RM252 and RM241 were flanking the resistance gene in both resistant accessions, we have used them to analyse the genetic diversity in the target region in order to identify a possible introgression from $O$. glaberrima into Gigante. Eight $O$. glaberrima varieties, including two resistant ones, and 12 O. sativa indica and japonica representative varieties with various degrees of susceptibility were tested.

The genetic diversity of $O$. glaberrima was very low and independent of resistance or susceptibility to RYMV (Fig. 2). In contrast, higher diversity was observed in $O$. sativa accessions. A clear-cut variation was observed between the two cultivated rice species, and only one allele was shared by both of them. Gigante showed a typical O. sativa microsatellite variation pattern on this chromosome portion.

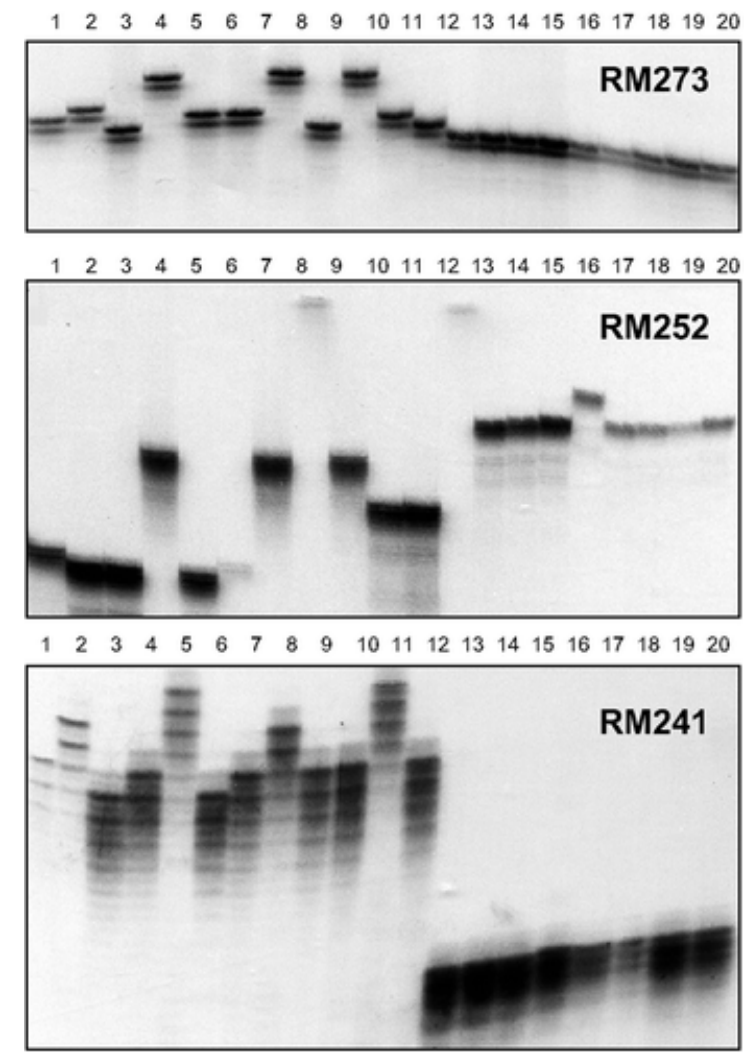

Fig. 2. Genetic diversity observed at three microsatellite loci spanning the RYMV resistance gene in different varieties of cultivated rice species (Oryza sativa and O. glaberrima). Lanes 1-6O. sativa japonica: 1 Haw Mom, 2 Cana Roxa, 3 Carolina, Gold, 4 Pate Blanc, 5 Azucena, 6 Nipponbare. Lanes 7-12O. sativa indica: 7 IR64, 8 Gigante, 9 IR5, 10 MTU9, 11 ASD1, 12 Carreon. Lanes 13-20O. glaberrima: 13 Tog5681, 14 Tog5672, 15 Tog5673, 16 IG10, 17 SG329, 18 CG14, 19 CG17, 20 CG20 


\section{Discussion}

We report genetic mapping of the RYMV resistance gene in rice varieties Gigante and Tog 5681. This work represents a prerequisite step for positional cloning of the resistance gene. We identified AFLP and microsatellite markers mapped at less than $2 \%$ recombination on both sides of the gene. The gene is located on chromosome 4 between microsatellite markers RM252 and RM273. Based on the distance between the CAPS marker M1 and the resistance gene in the IR64 $\times$ Gigante $F_{2}$ population $(14.3 \mathrm{cM})$ and on the location of M1 on the IR64 $\times$ Azucena map, the resistance gene was expected to be localized in the interval between RM241 and RM255 (Fig. 1). The actual position of the resistance gene indicated a drastic reduction of the map size in the considered region (about 50\%). Differences in map size are usually found in rice according to the parents used for the crosses (Antonio et al. 1996). In particular, distant indica $\times$ japonica crosses, like IR64 $\times$ Azucena, are known to lead to segregation distortion and recombination restriction, which can affect the mapping (Lorieux et al. 1995). Here we observed a surprisingly small map size for an indica $\times$ indica cross. Nevertheless, the utilisation of a reference map in our work was very effective for rapidly targeting microsatellite markers and closely tagging a gene of interest. The intra- and interspecific mapping data were coherent with the genetic analysis results of Ndjiondjop et al. (1999) and confirmed that we had mapped the same locus in the two resistant Gigante and Tog 5681 varieties.

In some species with a large genome and a high percentage of repeated sequences, such as barley or wheat, map-based cloning requires molecular markers mapped at $0.5 \mathrm{cM}$ of the gene of interest, or even closer (Kilian et al. 1997; Stein et al. 2000). In rice, Chen et al. (2002) estimated the ratio physical distance/genetic distance on the different part of the genome. In the region of the RYMV resistance gene, this ratio is about $200 \mathrm{~kb} / \mathrm{cM}$. That means about $750 \mathrm{~kb}$ between the closest markers flanking the resistance gene, or six BACs, considering an average of $125 \mathrm{~kb}$ per BAC for the HindIII and EcoRI BACs libraries from the Nipponbare variety (Chen et al. 2002). This physical distance is estimated to be short enough to start physical mapping of the region surrounding the gene. A lot of data are available in chromosome 4, such as the physical map (Chen et al. 2002; Zhao et al. 2002) and sequences of japonica or indica BACs (Zhao et al. 2002). Moreover, complete draft sequences of the rice genome have been published (Barry 2001; Goff et al. 2002; Yu et al. 2002). These data will be used to isolate the gene. First, sequence alignment of AFLP or microsatellite markers 
on BACs or genomic sequences may greatly facilitate the physical mapping of the resistance gene. Then, new markers will be deduced from the sequences available, and gene annotations will permit the identification of candidate genes.

A large majority of cloned resistance genes are NBS-type genes involved in gene-for-gene interactions and hypersensitive reactions, and they often occur in clusters (Ellis et al. 2000). They are usually dominant, and the susceptible phenotype corresponds to the absence of the functional copy of the gene and not to the presence of a susceptible allele. In some cases, no copy has been found at the allelic position in susceptible genotypes (Grant et al. 1998). However, we do not expect a NBS-type gene involved in gene-for-gene interactions to be the RYMV resistance gene. Indeed, Ndjiondjop et al. (2001) suggested that, in Gigante and Tog 5681 varieties, a constitutive mechanism could disrupt the infection process. This resistance could be caused by the mutation of a plant factor necessary for virus transport. According to this hypothesis, the susceptibility gene from IR64 or Nipponbare would code for a functional protein useful both for the plant and for the virus and should not be more difficult to isolate than the resistant allele.

This interaction model should be considered for the validation of candidate genes using a transformation approach. The apparent recessivity of this gene suggests transformation of a resistant genotype by the susceptibility allele isolated for instance from the Nipponbare or IR64 varieties. As first tests indicated low a transformation efficiency in Gigante, we are currently transferring the RYMV resistance gene in the Nipponbare genetic background by conventional backcrossing. A genotype possessing both the RYMV resistance and the exceptional yield of transformation of Nipponbare (Hiei et al. 1997) will thus be available to perform complementation. Alternative strategies could be developed according to the proposed host-pathogen interaction model. If the host component is a quantitative limiting factor, then direct transformation by the resistance allele coupled to overexpression of the transgene could efficiently shift the interaction in favour of the transgene and sufficiently modify the virus content or symptom expression patterns.

As high resistance to RYMV is very rare in the two cultivated rice species and the coexistence of $O$. glaberrima and $O$. sativa on the African continent is recent, we might wonder if the resistance of the Gigante variety could result from an O. glaberrima introgression. We used the microsatellite markers spanning the resistance gene to test this hypothesis and to identify eventual O. glaberrima alleles in Gigante. Results of our study evidenced a clear-cut variation between $O$. sativa and $O$. glaberrima - regardless of 
susceptibility or resistance to RYMV - which reflected more probably the divergence of these two species, as described by several evolutionary studies (Ishii et al. 1993; Second 1982). Gigante has a usual $O$. sativa profile for all three tested markers. Thus, these data are not in favour of an introgression. This was also supported by very little evidence of natural introgressions between the two cultivated rice species at any nuclear and cytoplasmic RFLP markers (Dally and Second 1989; Second 1982), which could be explained by the very strong reproductive barrier between the two species (Sano et al. 1979).

If we consider the proposed model of resistance based on an interaction between the virus and a host component to be required for cell-to cell movement of the virus, a point-mutation on this component could be sufficient to hamper this interaction and confer high resistance to RYMV. The rarity of this resistance in any rice varieties may be the result of natural mutations, regardless of improbable coevolution factors between African rice species and the virus. Mutations in resistant $O$. glaberrima and Gigante most likely occurred independently and probably at different positions in the sequence of the host component, which could affect the specificity of allele/virus isolate interactions. Recent laboratory experiments based on serial inoculations of Gigante and Tog 5681 have demonstrated that different strains of the virus characterised by their serological properties can overcome one of the resistant accessions but not both of them (Fargette et al. 2002). This suggests that different resistant alleles were involved. This diversity study will be further refined using markers closer to the gene as soon as they are available and, of course, sequences of the different alleles and their expression will be compared once the gene is isolated. Confirmation of different mutations in the sequence would aid in a to better understanding of the molecular basis of the interaction and provide a rationale for resistance deployment combining different types of natural resistance genes.

Acknowledgements. This work is a part of the "Interspecific Hybridization Project Between African and Asian Cultivated Rice Species" funded by the Ministry of Foreign Affairs of Japan through UNDP/TCDC contribution and by the Rockefeller foundation. M.-N. Ndjiondjop is the recipient of a $\mathrm{PhD}$ grant from the Rockefeller Foundation training program on rice biotechnology. We thank M. Lorieux for useful discussions and C. Brugidou for critical reading of the manuscript. We are also grateful to J. Aribi and T. Mathieu for technical assistance. 


\section{References}

Abo ME, Sy AA, Alegbejo MD (1998) Rice yellow mottle virus (RYMV) in Africa: evolution, distribution, economic significance on sustainable rice production and management strategies. J Sustain Agric 11:85-111

Albar L, Lorieux M, Ahmadi N, Rimbault I, Pinel A, Sy A, Fargette D, Ghesquière A (1998) Genetic basis and mapping of the resistance to Rice yellow mottle virus. I. QTLs identification and relationship between resistance and plant morphology. Theor Appl Genet 97:1145-1154

Allard RW (1956) Formulas and tables to facilitate the calculation of recombination values in heredity. Hilgardia 24:235-278

Antonio BA, Inoue T, Kajiya H, Nagamura Y, Kurata N, Minobe Y, Yano M, Nakagahra M, Sasaki $\mathrm{T}$ (1996) Comparison of genetic distance and order of DNA markers in five populations of rice. Genome 39:946-956

Barry G (2001) The use of the Monsanto draft rice genome sequence in research. Plant Physiol 125:1164-1165

Bendahmane A, Kanyuka K, Baulcombe DC (1999) The $R x$ gene from potato controls separate virus resistance and cell death responses. Plant Cell 11:781-791

Chen M, Presting G, Barbazuk W, Goicoechea J, Blackmon B, Fang G, Kim H, Frisch D, Yu Y, Sun S, Higingbottom S, Phimphilai J, Phimphilai D, Thurmond S, Gaudette B, Li P, Liu J, Hatfield J, Main D, Farrar K, Henderson C, Barnett L, Costa R, Williams B, Walser S, Atkins M, Hall C, Budiman M, Tomkins J, Luo M, Bancroft I, Salse J, Regad F, Mohapatra T, Singh N, Tyagi A, Soderlund C, Dean R, Wing R (2002) An integrated physical and genetic map of the rice genome. Plant Cell 14:537-545

Chen X, Temnykh S, Xu Y, Cho YG, McCouch SR (1997) Development of a microsatellite framework map providing genome-wide coverage in rice (Oryza sativa L.). Theor Appl Genet 95:553-567

Chisholm ST, Mahajan SK, Witham SA, Yamamoto ML, Carrington JC (2000) Cloning of the Arabidopsis RTM1 gene, which controls restriction of long-distance movement of Tobacco etch virus. Proc Natl Acad Sci USA 97:489-494

Dally A, Second G (1989) Chloroplast DNA diversity in wild and cultivated species of rices (genus Oryza, section Oryza). Cladistic-mutation and genetic-distance analysis. Theor Appl Genet 80:209-222

Ellis J, Dodds P, Pryor T (2000) Structure, function and evolution of plant disease resistance genes. Curr Opin Plant Biol 3:278-284

Fargette D, Pinel A, Traoré O, Ghesquière A, Konaté G (2002) Emergence of resistance-breaking isolates of Rice yellow mottle virus during serial inoculations. Eur J Plant Pathol 108:585-591

Ghesquière A, Lorieux M, Roumen E, Albar L, Fargette D, Huang N, Notteghem JL (1996)

Indica/japonica doubled haploid population as a model for mapping rice yellow mottle virus and blast resistance genes. Int Rice Res Notes 21:47-49

Gibb K, Hellmann G, Pirone T (1989) Nature of resistance of a tobacco cultivar to Tobacco vein mottling virus. Mol Plant-Microbe Interact 2:332-339

Goff S, Ricke D, Lan T, Presting G, Wang R, Dunn M, Glazebrook J, Sessions A, Oeller P, Varma H, Hadley D, Hutchinson D, Martin C, Katagiri F, Lange B, Moughamer T, Xia Y, Budworth P, Zhong J, Miguel T, Paszkowski U, Zhang S, Colbert M, Sun W, Chen L, Cooper B, Park S, Wood T, Mao L, Quail P, Wing R, Dean R, Yu Y, Zharkikh A, Shen R, Sahasrabudhe S, Thomas A, Cannings R, Gutin A, Pruss D, Reid J, Tavtigian S, Mitchell J, Eldredge G, Scholl T, Miller R, Bhatnagar S, Adey N, Rubano T, Tusneem N, Robinson R, Feldhaus J, Macalma T, Oliphant A, Briggs S (2002) A draft sequence of the rice genome (Oryza sativa L. ssp japonica). Science 296:92-100

Grant MR, Mcdowell JM, Sharpe AG, Zabala MDT, Lydiate DJ, Dangl JL (1998) Independent deletions of a pathogen-resistance gene in Brassica and Arabidopsis. Proc Natl Acad Sci USA 95:15,843-15,848

Guiderdoni E, Galinato E, Luistro J, Vergara G (1992) Anther culture of tropical japonica $\times$ indica hybrids of rice (Oryza sativa L.). Euphytica 62:219-224

Hiei Y, Komari T, Kubo T (1997) Transformation of rice mediated by Agrobacterium tumefaciens. Plant Mol Biol 35:205-218 
Huang N, Parco A, Mew T, Magpantay G, Mccouch SR, Guiderdoni E, Xu J, Subudhi P, Angeles ER, Khush GS (1997) RFLP mapping of isozymes, RAPD and QTLs for grain shape, brown planthopper resistance in a doubled haploid rice population. Mol Breed 3:105-113

Ishii T, Terachi T, Mori N, Tsunewaki K (1993) Comparative study on the chloroplast, mitochondrial and nuclear genome differentiation in the two cultivated rice species, Oryza sativa and Oryza glaberrima, by RFLP analyses. Theor Appl Genet 86:88-96

Kilian A, Chen J, Han F, Steffenson B, Kleinhofs A (1997) Towards map-based cloning of the barley stem rust resistance genes $R p g 1$ and $r p g 4$ using rice as an intergenomic cloning vehicle. Plant Mol Biol 35:187-195

Lander ES, Green P, Abrahamson J, Barlow A, Daly MJ, Lincoln SE, Newburg L (1987) MAPMARKER: an interactive computer package for constructing primary genetic linkage maps of experimental and natural populations. Genomics 1:174-181

Lorieux M, Goffinet B, Perrier X, Gonzales De Leon D, Lanaud C (1995) Maximum-likelihood models for mapping genetic markers showing segregation distorsion: 1. Backcross populations. Theor Appl Genet 90:73-80

Lorieux M, Petrov M, Huang N, Guiderdoni E, Ghesquière A (1996) Aroma in rice: genetic analysis of a quantitative trait. Theor Appl Genet 93:1145-1151

Lorieux M, Ndjiondjop M-N, Ghesquière A (2000) A first interspecific Oryza sativa × Oryza glaberrima microsatellite-based genetic linkage map. Theor Appl Genet 100:593-601

Michelmore RW, Paran I, Kesseli RY (1991) Identification of markers linked to disease-resistance genes by bulked segregant analysis: a rapid method to detect markers in specific genomic regions by using segregating populations. Proc Natl Acad Sci USA 88:9828-9832

Murray MG, Thompson WF (1980) Rapid isolation of high molecular weight plant DNA. Nucleic Acids Res 8:4321-4325

Ndjiondjop M-N, Albar L, Fargette D, Fauquet C, Ghesquière A (1999) The genetic basis of high resistance to Rice yellow mottle virus (RYMV) in cultivars of two cultivated rice species. Plant Dis 83:931-935

Ndjiondjop M-N, Brugidou C, Zang S, Fargette D, Ghesquière A, Fauquet C (2001) High resistance to Rice yellow mottle virus (RYMV) in two cultivated rice cultivars is correlated to the failure of cell-to-cell movement. Physiol Mol Plant Pathol 59:309-316

Sano Y, Chu YE, Oka HI (1979) Genetic studies of speciation in cultivated rice. I. Genic analyses on the F1 sterility between $O$. sativa L. and O. glaberrima Steud. Jpn J Genet 54:121-132

Second G (1982) Origin of the genic diversity of cultivated rice (Oryza spp). Study of the polymorphism scored at 40 isozyme loci. Jpn J Genet 57:25-57

Stein N, Feuillet C, Wicker T, Schlagenhauf E, Keller B (2000) Subgenome chromosome walking in wheat: a 450-kb physical contig in Triticum monococcum L. spans the Lr10 resistance locus in hexaploid wheat (Triticum aestivum L.). Proc Natl Acad Sci USA 97:13,436-13,441

Temnykh S, Park WD, Ayres N, Cartinhour S, Hauck N, Lipovich L, Cho Yg, Ishii T, Mccouch SR (2000) Mapping and genome organization of microsatellite sequences in rice (Oryza sativa L.). Theor Appl Genet 100:697-712

Thottappilly G, Rossel HW (1993) Evaluation of resistance to Rice yellow mottle virus in Oryza species. Indian J Virol 9:65-73

Vos P, Hogers R, Bleeker M, Reijans M, Van De Lee T, Hornes M, Fritjers A, Pot J, Peleman J, Kuiper M, Zabeau M (1995) AFLP: a new technique for DNA fingerprinting. Nucleic Acids Res 23:4407-4414

Whitham S, Dinesh-Kumar SP, Choi D, Hehl R, Corr C, Baker B (1994) The product of Tobacco mosaic virus resistance gene $N$ : similarity to Toll and the Interleukine-1 receptor. Cell 78:1101-1115

Whitham SA, Anderberg RJ, Chisholm ST, Carrington JC (2000) Arabidopsis RTM2 gene is necessary for specific restriction of Tobacco etch virus and encodes an unusual small heat shock-like protein.

Plant Cell 12:569-582 
Xu Y, Zhu L, Xiao J, Huang N, Mccouch SR (1997) Chromosomal regions associated with segregation distorsion of molecular markers in $\mathrm{F}_{2}$, backcross, doubled haploid, and recombinant inbred populations in rice (Oryza sativa L.). Mol Gen Genet 253:535-545

Yadav R, Courtois B, Huang N, McLaren G (1997) Mapping genes controlling root morphology and root distribution in a doubled-haploid population of rice. Theor Appl Genet 94:619-632

Yu J, Hu S, Wang J, Wong G, Li S, Liu B, Deng Y, Dai L, Zhou Y, Zhang X, Cao M, Liu J, Sun J, Tang J, Chen Y, Huang X, Lin W, Ye C, Tong W, Cong L, Geng J, Han Y, Li L, Li W, Hu G, Huang X, Li W, Li J, Liu Z, Li L, Liu J, Qi Q, Liu J, Li L, Li T, Wang X, Lu H, Wu T, Zhu M, Ni P, Han H, Dong W, Ren X, Feng X, Cui P, Li X, Wang H, Xu X, Zhai W, Xu Z, Zhang J, He S, Zhang J, Xu J, Zhang K, Zheng X, Dong J, Zeng W, Tao L, Ye J, Tan J, Ren X, Chen X, He J, Liu D, Tian W, Tian C, Xia H, Bao Q, Li G, Gao H, Cao T, Wang J, Zhao W, Li P, Chen W, Wang X, Zhang Y, Hu J, Wang J, Liu S, Yang J, Zhang G, Xiong Y, Li Z, Mao L, Zhou C, Zhu Z, Chen R, Hao B, Zheng W, Chen S, Guo W, Li G, Liu S, Tao M, Wang J, Zhu L, Yuan L, Yang H (2002) A draft sequence of the rice genome (Oryza sativa L. ssp indica). Science 296:79-92

Zhao Q, Zhang Y, Cheng Z, Chen M, Wang S, Feng Q, Huang Y, Li Y, Tang Y, Zhou B, Chen Z, Yu S, Zhu J, Hu X, Mu J, Ying K, Hao P, Zhang L, Lu Y, Zhang L, Liu Y, Yu Z, Fan D, Weng Q, Chen L, Lu T, Liu X, Jia P, Sun T, Wu Y, Zhang Y, Lu Y, Li C, Wang R, Lei H, Li T, Hu H, Wu M, Zhang R, Guan J, Zhu J, Fu G, Gu M, Hong G, Xue Y, Wing R, Jiang J, Han B (2002) A fine physical map of the rice chromosome 4. Genome Res 12:817-823 